\title{
Preparation of Cell Blocks for Lung Cancer Diagnosis and Prediction: Protocol and Experience of a High-Volume Center
}

\author{
Claudia A. Kossakowski ${ }^{a}$ Alicia Morresi-Hauf ${ }^{d}$ Philipp A. Schnabel ${ }^{a, c}$ \\ Ralf Eberhardt $^{\text {b }}$ Felix J.F. Herth ${ }^{b, c}$ Arne Warth ${ }^{a}$ \\ anstitute of Pathology, University Hospital Heidelberg, ${ }^{b}$ Department of Pneumology and Critical Care Medicine, \\ Thoraxklinik at Heidelberg University, and ' Translational Research Center Heidelberg (TLRC-H), Heidelberg, and \\ ${ }^{d}$ Institute of Pathology, Asklepios Hospital, München-Gauting, Germany
}

\section{Key Words}

Lung cancer · Diagnosis · Prediction · Cytology · Cell block

\begin{abstract}
Minimally invasive diagnostic techniques are increasingly being used to obtain specimens for pathological diagnosis and prediction. Referring to lung cancer, both endobronchial and endoesophageal ultrasound are used worldwide as diagnostic routine methods. Consequently, an increasing number of pathological samples are cytological and fewer are histological. On the other hand, the requirements for specific and sensitive tumor subtyping complemented by predictive analyses are steadily increasing and are an essential basis for evidence-based treatment decisions. In this article we focus on the cell block method as a helpful tool for diagnostic and predictive analyses in lung cancer and point out its advantages and disadvantages in comparison to conventional cytological and biopsy specimens. Furthermore, we retrospectively analyze the diagnostic results of the cell block method in a high-volume center over 5 years. The main advantages of cell blocks are the availability of established and validated protocols, archiving and the opportunity to have serial sections from the same specimens to provide or repeat molecular analyses. Actually, in case of tumor progression, even additional biomarkers can be tested using the original
\end{abstract}

cell block when re-biopsies are not feasible. The cell block method should be considered as a reliable, complimentary approach to conventional cytological or biopsy procedures, which is helpful to fulfill the increasing requirements of highquality diagnostics and prediction.

(c) 2014 S. Karger AG, Basel

\section{Introduction}

With about 1.4 billion deaths worldwide, lung cancer is still the leading cause of cancer-related mortality [1]. However, historical separation into small-cell lung cancer and non-small-cell lung cancer (NSCLC) is no longer adequate considering that morphological [2], immunohistochemical [3] and molecular characterization [4-6] of NSCLC entities significantly affect the prognoses of the patients and, thus, relevant clinical decisions in terms of appropriate therapy selection $[4,6]$. For example, NSCLC patients harboring activating mutations of the EGFR gene or translocations of $A L K$ [7] have a significantly better outcome when treated with tyrosine kinase inhibitors compared to standard chemotherapy $[4,6,8]$.

Philipp A. Schnabel and Felix J.F. Herth are members of the German Center for Lung Research (DZL).

\section{KARGER}

E-Mail karger@karger.com

www.karger.com/res
(C) 2014 S. Karger AG, Basel

0025-7931/14/0875-0432\$39.50/0
Arne Warth, MD

Institute for Pathology, University Hospital Heidelberg

Im Neuenheimer Feld 224

DE-69120 Heidelberg (Germany)

E-Mail arne.warth@med.uni-heidelberg.de 
Molecular pathological analyses of respective biomarkers are usually performed with different methods using tumor tissue and are frequently established in pathological institutions $[9,10]$. Methodologically, Sanger sequencing [11] is widely used in pathological institutions and potentially allows for the detection of all mutations in the analyzed exons; however, more sensitive methods for mutation detection are available and next generation sequencing approaches will likely take the lead in the near future. Major limitations of Sanger sequencing refer to a lack of sensitivity since a tumor content of about $30 \%$ (without microdissection) is required for reliable results [12]. Therefore, one important aspect for reliable results is the amount of tumor in the analyzed specimens which needs to be sufficient for more and more complex morphological, immunohistochemical and molecular tumor subtyping. Hence, there is an increasing number of guidelines and recommendations to be considered for standardized and evidence-based material processing, analysis and reporting of the results [10,13-16].

\section{Aspects of Tumor Sampling}

Even in the recently published guideline of the American College of Chest Physicians it is clearly stated that the nowadays minimal invasive diagnostic techniques should be used as the first test [17]. Therefore, besides conventional transbronchial needle aspiration (TBNA), endobronchial ultrasound and endoesophageal ultrasound, and especially the combination of both, are increasingly used worldwide as the primary diagnostic methods [1821]. However, this also means that most of the available material is shifted from being histological to cytological. Therefore, the diagnostic yield of cytological specimens has to be improved. In general, the total number of tumor cells is the most important issue for molecular analyses, especially if there is no option for microdissection.

\section{Cell Blocks for Diagnostic and Predictive Analyses}

Up to now there have been only a few recommendations for molecular biomarker tests using cytological specimens. Round robin trials as established for tissue specimens $[9,10]$ would be essential for the establishment of an international, quality-approved standard. Within this context respective algorithms need to be defined considering both the requirements for diagnostic and predictive analyses.

Preparation of Cell Blocks for Lung

Cancer Diagnosis and Prediction
Major advantages of conventional cytological specimens are the intactness of the cell nuclei and the high DNA quality, usually allowing good morphological and especially molecular analyses, e.g. fluorescence in situ hybridizations (FISH). Limitations refer predominantly to the limited number of tumor cells. Furthermore, changes of the original specimen by microdissection for molecular analyses, for example, may pose a problem considering the archiving requirements of original slides, since relevant diagnostic features may no longer be evident. In such cases image-guided documentation of the slides are mandatory prior to the dissection of tumor cells. In addition, established criteria for predictive analyses using tissue specimens must be adapted to the cytological specimens in some cases [22].

Among the advantages of cell blocks, archiving of the specimens is of utmost importance. With the availability of established and validated protocols (see below), cell blocks provide the opportunity to cut serial sections from the same specimens, even weeks or months after the initial diagnoses or when the tumor relapses and rebiopsies are not feasible. Furthermore, changes to the original slide due to molecular analyses (microdissection) can be avoided. Molecular analyses can even be repeated or complemented by other methods using the available serial sections [23]. Disadvantages of cell blocks compared to conventional cytology approaches refer to the sometimes reduced morphological quality (due to the spin down during processing), although others have even reported cell blocks to be helpful for a better demonstration of architectural patterns compared to ThinPrep specimens [24]. Moreover, one has to consider that cell nuclei are cut as in conventional biopsy specimens, which needs to be considered, for example, for FISH evaluation. The amount of extracted DNA for molecular analyses is consequently reduced compared to intact cells in conventional cytology probes. The following points need to be considered for molecular analyses using cell block material: (1) at least 50-100 tumor cells are required for respective analyses, as few as possible contaminated with non-neoplastic cells, and (2) specimens should be fixed with buffered formalin (defined $\mathrm{pH}$ and buffer capacity) - Bouin's solution should be avoided because the picric acid results in DNA damage and thus significantly impairs molecular analyses.

The preconditions for reliable molecular analyses using cytological specimens are experience, high expertise in cytology and sufficient technical equipment, as well as a direct communication between the histopathologists and cytologists involved in the case and those who perform the 

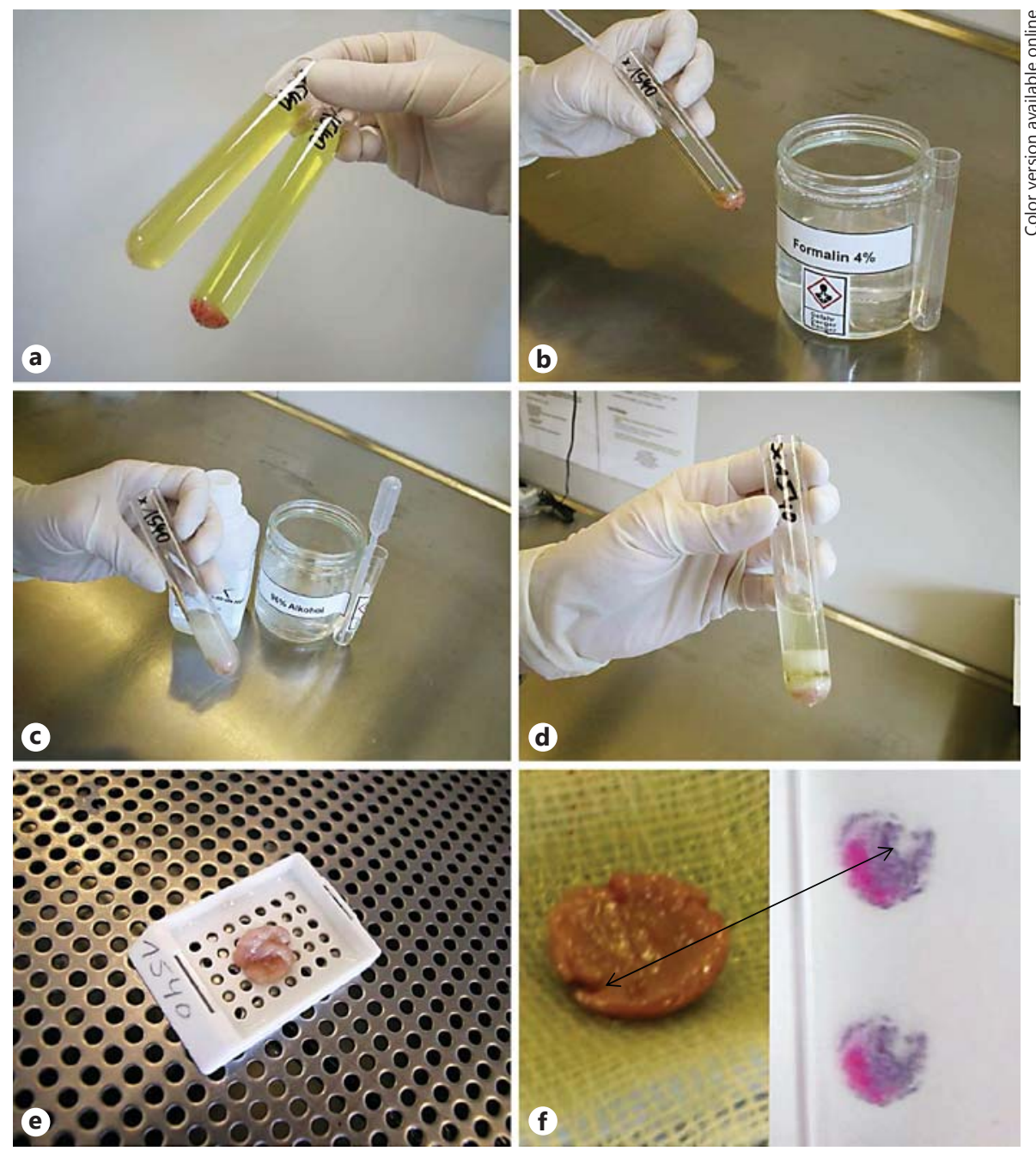

Fig. 1. Recommended protocol for the preparation of cell blocks.

molecular analyses in order to ultimately correlate all respective results. It is emphasized that cell blocks do not replace conventional cytological procedures (smears, cytospins) but are especially helpful as a complementary approach $[24,25]$ to fulfill the requirements of reliable and high-quality predictive biomarker analyses. Cell blocks allow different diagnostic (hematoxylin and eosin, histochemistry, immunohistochemistry) and predictive molecular analyses, long-term archiving and processing of relatively large amounts of body fluids with high diagnostic yield, for example using TBNA material of several needle passages. After sampling, cytological probes should be kept within a temperature of $2-8^{\circ} \mathrm{C}$ (not frozen) or suitable fixatives (e.g. neutrally buffered formalin).

There are various protocols published for the preparation of cell blocks [24, 26-32], usually using the plasmathrombin method or agar to obtain coagulated probes.
However, at least in Germany, the Gauting protocol is frequently used and was also optimized and validated for several years by members of the Working Group for Pulmonary Pathology of the German Society for Pathology [33]. The following protocol was approved in a multicenter setting and is suitable and reliable for all kinds of molecular analyses (see also fig. 1).

(1) Fill the cytological probes in a centrifuge tube and spin down with 4,000 U/min for $10 \mathrm{~min}$ (fig. 1a).

(2) Transfer the supernatant into another tube for storage - it is recommended to do some smears from the sediment.

(3) Add 1-2 $\mathrm{ml}$ of formalin to the sediment and mix it thoroughly (fig. 1b), spin down shortly (4,000 U/min) after $15 \mathrm{~min}$ and remove the supernatant.

(4) Slowly add 2-3 T drips of protein glycerol (for example from Morphisto GmbH, Frankfurt, Germany, Ref 
Fig. 2. Retrospective analyses of the diagnostic yield of the cell block method in lung cancer diagnostics. The herein described cell block protocol was applied over a period of 5 years. The presented data of 631 pulmonary or mediastinal lesions refer to a retrospective analysis of all cases potentially suspicious for malignancy (unclear pulmonary lesion). Diagnoses were grouped in 'sarcoidosis' when clear non-necrotizing granulomas were evident, 'tumor' when cytology alone was sufficient for a reliable tumor diagnosis, 'suspicious for malignancy' when additional analyses were required to rule out or to confirm malignancy, or 'no specific diagnosis' when there were no cytological correlates for the clinically described lesion. Cases in which additional immunohistochemical analyses were performed were further grouped in 'tumor' if a final tumor (sub-)typing was possible, 'no tumor' if a tumor diagnosis could not be substantiated or 'no material on serial sections'. In a few cases the final tumor subtyping was achieved using biopsy material obtained in parallel ('tumor subtyping on biopsies'). Taken together, in 35\% of all cases a specific diagnosis was possible using cell block specimens. In $21.5 \%$ of the nondiagnostic cases ('no specific diagnosis') a final diagnosis was made in biopsies obtained in parallel. $\mathrm{HE}=$ Hematoxylin and eosin, IHC = immunohistochemistry, PAS $=$ periodic acid-Schiff stain, SCLC = small-cell lung cancer.

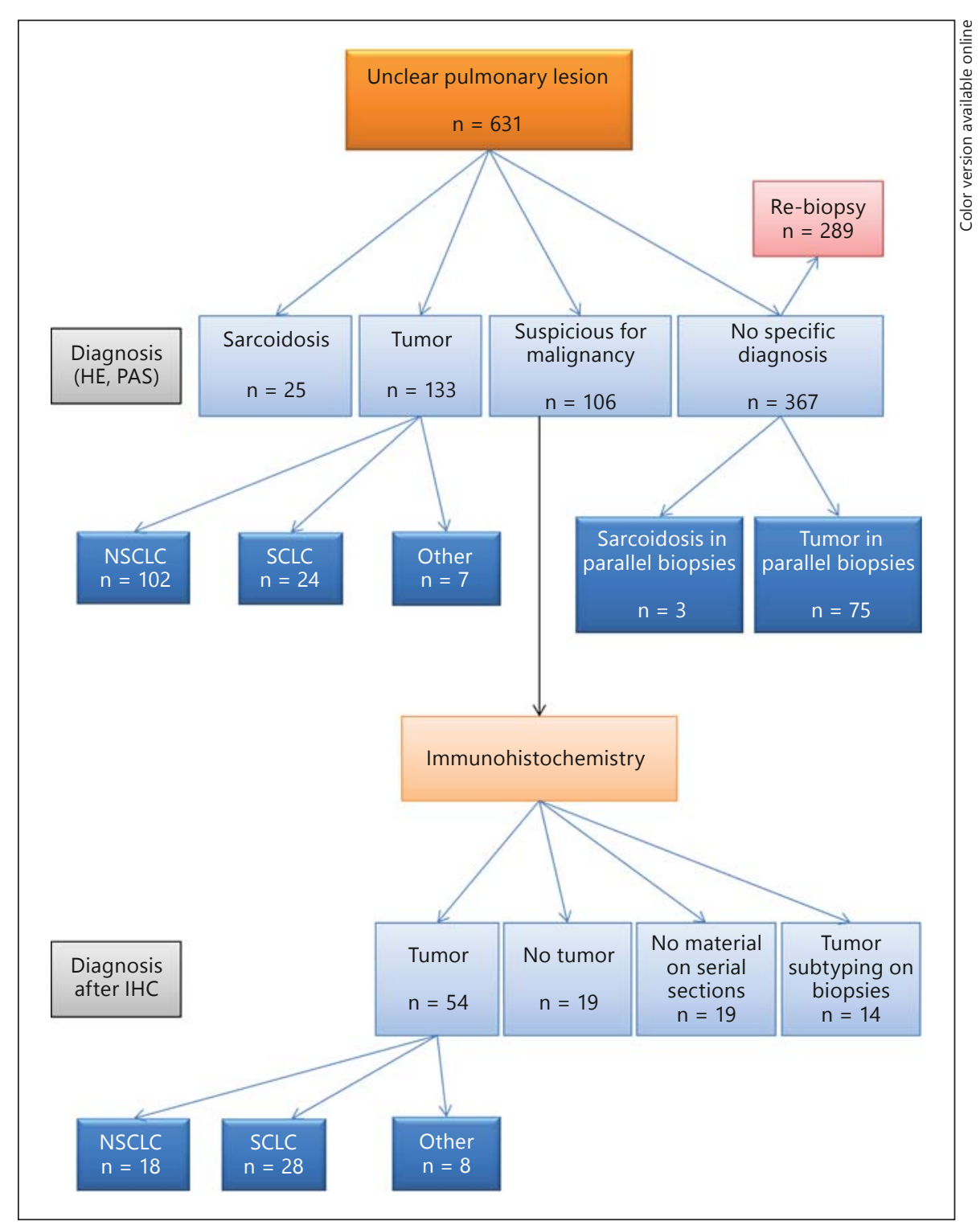

13247.00250) and 1.5-2 $\mathrm{ml}$ of $96 \%$ alcohol and mix it up thoroughly until visible flocculation occurs (fig. 1c), then spin down at 4,000 $\mathrm{U} / \mathrm{min}$ for $5 \mathrm{~min}$.

Remark: Adding histological dyes is not necessary since the cytological material is usually visible due to the admixture of blood. Furthermore, eosin can lead to an increased autofluorescence of the cells which might be critical for FISH analyses.

(5) Immediately detach the coagulated material from the bottom with an applicator (fig. 1d, e) and take care that the removed probe is not completely round but has some clear landmarks in the periphery, which allows for a much better recognition of tumor cell-containing areas in serial sections and is especially helpful for subsequent microdissection by a pathologist or even the technical personal (fig. 1f).

(6) Place the probe in a cassette, further processing analogous to conventional histological specimens.

Remark: Adding protein glycerol and repeated centrifugation is only necessary if no spontaneous coagulation occurs.

After establishment and improvement of the protocol by different pathological institutions and working groups, the diagnostic results were retrospectively analyzed in a single center over 5 years. The respective data are provided in figure 2. 


\section{Discussion}

Since the vast majority of patients are inoperable at diagnosis, there is usually only sparse tumor material available. In order to fulfill the increasing requirements of high-quality diagnostics and prediction for lung cancer, rational usage of the tissue as well as optimization of respective methods and algorithms is essential [13, 15]. In up to $40 \%$ of cases the diagnoses are made on cytological material [34]. Furthermore, one must be aware that especially patients with nonresectable tumors might benefit from targeted therapies. All available material should be tested for established predictive biomarkers. In NSCLC cases with unclear histomorphology, which is actually the case in up to $30 \%$ of biopsies [3], the required phenotyping by immunohistochemical markers should be done with a few specific and sensitive immunomarkers (TTF-1, napsin, p63, CK5/6) in order to save tumor material for subsequent predictive analyses.

Essentially, all additionally required analyses for subtyping or prediction can be performed using cytological material [22, 34-40]. The main advantage of cytological specimens, compared to biopsy specimens, comes from the fact that they are usually less contaminated by non-neoplastic cells which might hamper specific and sensitive analyses. In contrast to many protocols reported before (see above), which are often inconvenient or time consuming and thus not suitable in a routine pathology setting, the herein reported, independently validated protocol for the preparation of cell blocks has the advantage of an improved handling of the coagulated material. In contrast to the plasmathrombin method the protocol results in a firm specimen. Thus, there is no risk of losing material during the transfer of the probe or subsequent processing. Furthermore, all necessary compounds are commercially available, have no hazardous potential and, most importantly, do not result in DNA damage. Therefore, it is suitable for fast and reliable diagnostic and predictive analyses under routine conditions.

Considering that molecular diagnostic approaches are becoming more and more sensitive and mutations can already be detected in free-circulating DNA, usage of pooled human plasma samples for cell block preparation of other individuals might also be critical with respect to potential contaminations. However, respective data are so far missing.

Based on the various aspects outlined above and according to our experience, the following points are rec- ommended in order to improve the quality of predictive molecular analyses using cytological specimens. Independently from the respective method, as much tumor material as possible is required by pathologists in order to provide high-quality diagnostic and predictive analyses. Sputum and bronchoalveolar lavage specimens should be combined with another approach to gain sufficient amounts of tumor cells (TBNA or biopsy approaches). If a transport of the specimens is required, this should be done in liquid form using suitable fixatives or at $2-8^{\circ} \mathrm{C}$. Freezing of the specimens should be avoided.

Besides smears or cytospins, preparation of a cell block from each cytological probe should be aimed for in order to optimize the subsequent molecular analyses. We recommend preparation of cell blocks immediately after a malignant diagnosis has been made using the sediment of the original probe stored at $4^{\circ} \mathrm{C}$. For reasons of efficiency, we prepare cell blocks from endobronchial ultrasoundTBNA material and all specimens suspicious for malignancy immediately from the beginning of the diagnostic procedures.

All kinds of diagnostic or predictive analyses can be performed using cytological or sparse biopsy material. Even if only cytological material is available, predictive analyses should nevertheless be performed.

In conclusion, even sparse tumor material can be used for diagnostic and predictive analyses without significant restrictions considering the outlined limitations. The discussed aspects of various biopsy approaches and processing of the specimens are of increasing relevance in the multidisciplinary care of lung cancer patients.

References

Siegel R, Naishadham D, Jemal A: Cancer sta-
tistics, 2013. CA Cancer J Clin 2013;63:11-30.
2 Warth A, Muley T, Meister M, Stenzinger A,
Thomas M, Schirmacher P, Schnabel PA,
Budczies J, Hoffmann H, Weichert W: The
novel histologic International Association
for the Study of Lung Cancer/American
Thoracic Society/European Respiratory So-
ciety classification system of lung adeno-
carcinoma is a stage-independent predictor
of survival. J Clin Oncol 2012;30:1438-
1446.
Warth A, Muley T, Herpel E, Meister M,
Herth FJ, Schirmacher P, Weichert W, Hoff-
mann H, Schnabel PA: Large-scale compara-
tive analyses of immunomarkers for diagnos-
tic subtyping of non-small-cell lung cancer
biopsies. Histopathology 2012;61:1017-
1025.

Kossakowski/Morresi-Hauf/Schnabel/ Eberhardt/Herth/Warth 
4 Kwak EL, Bang YJ, Camidge DR, Shaw AT, Solomon B, Maki RG, Ou SH, Dezube BJ, Janne PA, Costa DB, Varella-Garcia M, Kim WH, Lynch TJ, Fidias P, Stubbs H, Engelman JA, Sequist LV, Tan W, Gandhi L, Mino-Kenudson M, Wei GC, Shreeve SM, Ratain MJ, Settleman J, Christensen JG, Haber DA, Wilner K, Salgia R, Shapiro GI, Clark JW, Iafrate AJ: Anaplastic lymphoma kinase inhibition in non-small-cell lung cancer. N Engl J Med 2010;363:1693-1703.

5 Mok TS: Personalized medicine in lung cancer: what we need to know. Nat Rev Clin Oncol 2011;8:661-668.

6 Mok TS, Wu YL, Thongprasert S, Yang CH, Chu DT, Saijo N, Sunpaweravong P, Han B, Margono B, Ichinose Y, Nishiwaki Y, Ohe Y, Yang JJ, Chewaskulyong B, Jiang H, Duffield EL, Watkins CL, Armour AA, Fukuoka M: Gefitinib or carboplatin-paclitaxel in pulmonary adenocarcinoma. N Engl J Med 2009; 361:947-957.

-7 Soda M, Choi YL, Enomoto M, Takada S, Yamashita Y, Ishikawa S, Fujiwara S, Watanabe $\mathrm{H}$, Kurashina K, Hatanaka H, Bando M, Ohno S, Ishikawa Y, Aburatani H, Niki T, Sohara Y, Sugiyama Y, Mano H: Identification of the transforming EML4-ALK fusion gene in nonsmall-cell lung cancer. Nature 2007;448:561566.

8 Rosell R, Carcereny E, Gervais R, Vergnenegre A, Massuti B, Felip E, Palmero R, GarciaGomez R, Pallares C, Sanchez JM, Porta R, Cobo M, Garrido P, Longo F, Moran T, Insa A, De Marinis F, Corre R, Bover I, Illiano A, Dansin E, de Castro J, Milella M, Reguart N, Altavilla G, Jimenez U, Provencio M, Moreno MA, Terrasa J, Munoz-Langa J, Valdivia J, Isla D, Domine M, Molinier O, Mazieres J, Baize N, Garcia-Campelo R, Robinet G, Rodriguez-Abreu D, Lopez-Vivanco G, Gebbia V, Ferrera-Delgado L, Bombaron P, Bernabe R, Bearz A, Artal A, Cortesi E, Rolfo C, Sanchez-Ronco M, Drozdowskyj A, Queralt C, de Aguirre I, Ramirez JL, Sanchez JJ, Molina MA, Taron M, Paz-Ares L: Erlotinib versus standard chemotherapy as first-line treatment for European patients with advanced EGFR mutation-positive non-small-cell lung cancer (EURTAC): a multicentre, open-label, randomised phase 3 trial. Lancet Oncol 2012; 13:239-246.

9 V Laffert M, Warth A, Penzel R, Schirmacher P, Jonigk D, Kreipe H, Schildhaus HU, Merkelbach-Bruse S, Buttner R, Reu S, Kerler R, Jung A, Kirchner T, Wolfel C, Petersen I, Rodriguez R, Jochum W, Bartsch H, Fisseler-Eckhoff A, Berg E, Lenze D, Dietel M, Hummel M: Anaplastic lymphoma kinase (ALK) gene rearrangement in non-small cell lung cancer (NSCLC): results of a multi-centre ALK-testing. Lung Cancer 2013;81:200206.

10 Penzel R, Sers C, Chen Y, Lehmann-Muhlenhoff U, Merkelbach-Bruse S, Jung A, Kirchner T, Buttner R, Kreipe HH, Petersen I, Dietel M, Schirmacher P: EGFR mutation detection in
NSCLC-assessment of diagnostic application and recommendations of the German Panel for Mutation Testing in NSCLC. Virchows Arc 2011;458:95-98.

-11 Sanger F, Nicklen S, Coulson AR: DNA sequencing with chain-terminating inhibitors. Proc Nat Acad Sci 1977;74:5463-5467.

12 Warth A, Penzel R, Brandt R, Sers C, Fischer JR, Thomas M, Herth FJ, Dietel M, Schirmacher P, Blaker H: Optimized algorithm for sanger sequencing-based EGFR mutation analyses in NSCLC biopsies. Virchows Arc 2012;460:407-414.

$\checkmark 13$ Thunnissen E, Kerr KM, Herth FJ, Lantuejoul S, Papotti M, Rintoul RC, Rossi G, Skov BG, Weynand B, Bubendorf L, Katrien G, Johansson L, Lopez-Rios F, Ninane V, Olszewski W, Popper H, Jaume S, Schnabel P, Thiberville L, Laenger F: The challenge of NSCLC diagnosis and predictive analysis on small samples: practical approach of a working group. Lung Cancer 2012;76:1-18.

-14 Pirker R, Herth FJ, Kerr KM, Filipits M, Taron M, Gandara D, Hirsch FR, Grunenwald D, Popper H, Smit E, Dietel M, Marchetti A, Manegold C, Schirmacher P, Thomas M, Rosell R, Cappuzzo F, Stahel R: Consensus for EGFR mutation testing in non-small cell lung cancer: results from a European workshop. J Thorac Oncol 2010;5:1706-1713.

15 Travis WD, Brambilla E, Noguchi M, Nicholson AG, Geisinger KR, Yatabe Y, Beer DG, Powell CA, Riely GJ, Van Schil PE, Garg K, Austin $\mathrm{JH}$, Asamura H, Rusch VW, Hirsch FR, Scagliotti G, Mitsudomi T, Huber RM, Ishikawa Y, Jett J, Sanchez-Cespedes M, Sculier JP, Takahashi T, Tsuboi M, Vansteenkiste J, Wistuba I, Yang PC, Aberle D, Brambilla C, Flieder D, Franklin W, Gazdar A, Gould M, Hasleton P, Henderson D, Johnson B, Johnson D, Kerr K, Kuriyama K, Lee JS, Miller VA, Petersen I, Roggli V, Rosell R, Saijo N, Thunnissen E, Tsao M, Yankelewitz D: International Association for the Study of Lung Cancer/American Thoracic Society/European Respiratory Society: international multidisciplinary classification of lung adenocarcinoma. J Thorac Oncol 2011;6:244-285.

16 Lindeman NI, Cagle PT, Beasley MB, Chitale DA, Dacic S, Giaccone G, Jenkins RB, Kwiatkowski DJ, Saldivar JS, Squire J, Thunnissen E, Ladanyi M: Molecular testing guideline for selection of lung cancer patients for EGFR and ALK tyrosine kinase inhibitors: guideline from the College of American Pathologists, International Association for the Study of Lung Cancer, and Association for Molecular Pathology. J Mol Diagn 2013; 15:415-453.

17 Rivera MP, Mehta AC, Wahidi MM: Establishing the diagnosis of lung cancer: Diagnosis and Management of Lung Cancer, 3rd ed: American College of Chest Physicians evidence-based clinical practice guidelines. Chest 2013;143(suppl 5):e142S-e165S.

18 Gompelmann D, Eberhardt R, Herth FJ: Advanced malignant lung disease: what the spe- cialist can offer. Respiration 2011;82:111123.

19 Shure D, Fedullo PF: Transbronchial needle aspiration in the diagnosis of submucosal and peribronchial bronchogenic carcinoma. Chest 1985;88:49-51.

-20 Kacar N, Tuksavul F, Edipoglu O, Ermete S, Guclu SZ: Effectiveness of transbronchial needle aspiration in the diagnosis of exophytic endobronchial lesions and submucosal/ peribronchial diseases of the lung. Lung Cancer 2005;50:221-226.

-21 Herth FJ, Krasnik M, Kahn N, Eberhardt R, Ernst A: Combined endoscopic-endobronchial ultrasound-guided fine-needle aspiration of mediastinal lymph nodes through a single bronchoscope in 150 patients with suspected lung cancer. Chest 2010;138:790794

22 Zlobec I, Raineri I, Schneider S, Schoenegg R, Grilli B, Herzog M, Savic S, Bubendorf L: Assessment of mean EGFR gene copy number is a highly reproducible method for evaluating FISH in histological and cytological cancer specimens. Lung Cancer 2010;68:192197.

23 Cai G, Wong R, Chhieng D, Levy GH, Gettinger SN, Herbst RS, Puchalski JT, Homer RJ, Hui P: Identification of EGFR mutation, KRAS mutation, and ALK gene rearrangement in cytological specimens of primary and metastatic lung adenocarcinoma. Cancer $\mathrm{Cy}$ topathol 2013;121:500-507.

-24 Thapar M, Mishra RK, Sharma A, Goyal V: Critical analysis of cell block versus smear examination in effusions. J Cytol 2009;26:6064.

25 Shivakumarswamy U, Arakeri SU, Karigowdar MH, Yelikar B: Diagnostic utility of the cell block method versus the conventional smear study in pleural fluid cytology. J Cytol 2012;29:11-15.

26 Bubendorf L, Feicher G, Obermann P, Dalquen P: Zytopathologie: Pathologie, Band 9. Berlin, Springer, 2011.

27 Weihmann J, Weichert C, Petersen I, Gajda M: Evaluation of a cell block method in cytological diagnostics (in German). Pathologe 2012;33:553-559.

28 Nathan NA, Narayan E, Smith MM, Horn MJ: Cell block cytology: improved preparation and its efficacy in diagnostic cytology. Am J Clin Pathol 2000;114:599-606.

29 Mayall F, Chang B, Darlington A: A review of 50 consecutive cytology cell block preparations in a large general hospital. J Clin Pathol 1997;50:985-990.

30 Gupta S, Halder K, Khan VA, Sodhani P: Cell block as an adjunct to conventional Papanicolaou smear for diagnosis of cervical cancer in resource-limited settings. Cytopathology 2007;18:309-315.

31 Nigro K, Tynski Z, Wasman J, Abdul-Karim F, Wang N: Comparison of cell block preparation methods for nongynecologic ThinPrep specimens. Diagn Cytopathol 2007;35:640643.
Preparation of Cell Blocks for Lung

Cancer Diagnosis and Prediction 
32 Kulkarni MB, Desai SB, Ajit D, Chinoy RF: Utility of the thromboplastin-plasma cellblock technique for fine-needle aspiration and serous effusions. Diagn Cytopathol 2009; 37:86-90.

33 Warth A, Bubendorf L, Gutz S, Morresi-Hauf A, Hummel M, Junker K, Lehmann U, Petersen I, Schnabel PA: Molecular pathological diagnosis in cytopathology of non-small-cell lung cancer: standardization of specimen processing (in German). Pathologe 2013;34:310317.

34 Savic S, Bihl MP, Bubendorf L: Non-small cell lung cancer: subtyping and predictive molecular marker investigations in cytology (in German). Pathologe 2012;33:301-307.

-35 Tapia C, Savic S, Bihl M, Rufle A, Zlobec I, Terracciano L, Bubendorf L: [EGFR mutation analysis in non-small-cell lung cancer: Experience from routine diagnostics]. Pathologe 2009;30:384-392.
Savic S, Tapia C, Grilli B, Rufle A, Bihl MP, de Vito Barascud A, Herzog M, Terracciano L, Baty F, Bubendorf L: Comprehensive epidermal growth factor receptor gene analysis from cytological specimens of non-small-cell lung cancers. J Cancer 2008;98:154-160.

37 Bruno P, Mariotta S, Ricci A, Duranti E, Scozzi D, Noto A, Mancini R, Giarnieri E, Giovagnoli MR: Reliability of direct sequencing of EGFR: comparison between cytological and histological samples from the same patient. Anticancer Res 2011;31:4207-4210.
8 Rekhtman N, Brandt SM, Sigel CS, Friedlander MA, Riely GJ, Travis WD, Zakowski MF, Moreira AL: Suitability of thoracic cytology for new therapeutic paradigms in non-small cell lung carcinoma: high accuracy of tumor subtyping and feasibility of EGFR and KRAS molecular testing. J Thorac Oncol 2011;6: 451-458.

39 Solomon SB, Zakowski MF, Pao W, Thornton RH, Ladanyi M, Kris MG, Rusch VW, Rizvi NA: Core needle lung biopsy specimens: adequacy for EGFR and KRAS mutational analysis. Am J Roentgenol 2010;194:266-269.

40 Chowdhuri SR, Xi L, Pham TH, Hanson J, Rodriguez-Canales J, Berman A, Rajan A, Giaccone G, Emmert-Buck M, Raffeld M, Filie AC: EGFR and KRAS mutation analysis in cytologic samples of lung adenocarcinoma enabled by laser capture microdissection. Mod Pathol 2012;25:548-555. 